Journal of Maternal and Child Health (2019), 4(6): 48-56

https://doi.org/10.26911/thejmch.2019.04.06.05

\title{
The Relationship between Social Economic Levels and Anemia Events in Pregnant Women in Glugur Darat Health Center
}

\author{
Berliana Noviyanti, Harry C Simanjuntak, Eka Samuel P Hutasoit, \\ Hendrika A Silitonga, Endy Julianto
}

Faculty of Medicine, Universitas Methodist Indonesia

\begin{abstract}
Background: Anemia is a condition where the hemoglobin level in the blood was lower than normal. Anemia diagnosed when the hemoglobin level was $<11 \mathrm{gr} / \mathrm{dl}$ in the first and third trimesters or $<10.5 \mathrm{gr} \%$ in the second trimester in pregnant women. WHO stated in 2010 that $40 \%$ of the causes of maternal mortality in developing countries were associated with anemia in pregnancy. Based on the Riskesdas (Basic Health Research) in 2013, the prevalence of anemia in pregnant women in Indonesia was $37.1 \%$. One of the factors that influenced the incidence of anemia in pregnant women was the socio-economic level. The purpose of this study was to determine the relationship between socio-economic level and the incidence of anemia in pregnant women at the Glugur Darat Health Center.

Subjects and Method: This was an analytical study with a cross sectional approach, conducted at Glugur Darat health center, Medan in 2018. Total 65 pregnant women were selected by consecutive sampling. The independent were the education level, job status, income level. The dependent variable was the incidence of anemia in pregnant women. Data obtained by a set of questionnaire. The data analysis was conducted using Chi Square test.

Results: As many as 40 pregnant women (61.5\%) had anemia and 25 (38.5\%) who were not anemic. 34 people (85.0\%) among pregnant women with anemia was in the non-risk group, and 22 people in the Multi-gravida group (55.0\%), 16 (40.0\%) people in the Primipara group, 27 people (67.5\%) in Trimester gestational age III. As many as 28 people (70.0\%) had secondary education. Based on occupational 31 people (77.5\%) was not working, 19 people (47.5\%) had medium income.

Conclusion: There was no significant relationship between the level of education, occupational status, and income level with the incidence of anemia in pregnant women.
\end{abstract}

Keywords: education, employment, income, anemia, pregnant women.

\section{Correspondence:}

Berliana Noviyanti. Faculty of Medicine, Universitas Methodist Indonesia, Medan, Sumatra Utara. Email: berliana.noviyanti55@gmail.com.

\section{BACKGROUND}

Anemia is a condition where the hemoglobin level in the blood was lower than normal. Anemia diagnosed when the hemoglobin level was <11 gr / dl in the first and third trimesters or $<10.5 \mathrm{gr} \%$ in the second trimester in pregnant women. When hemoglobin levels decreased, the capacity of blood to carry oxygen to the tissues was disrupted, resulting in symptoms such as fati- gue, reduced physical work capacity and if it occurs in pregnancy, associated with poor birth outcomes (including low birth weight and prematurity) and maternal and perinatal mortality. Thus, anemia had significant consequences for human health and social and economic development in low, middle and high income countries (WHO, 2017).

Data from the 2010 World Health Organization (WHO) stated that $40 \%$ of the causes of maternal mortality in developing 
countries are associated with anemia in pregnancy. Anemia in pregnancy is a major health problem in developing countries with high levels of pain in pregnant women. Its prevalence is very high in Africa, Asia, India, Latin America, Western Europe, and China (Api et al, 2015). According to WHO, in developing countries the prevalence of anemia among pregnant women is on average $56 \%$, ranging from 35 to $100 \%$ in various regions of the world (Maskey, 2014).

Based on the results of the Household Health Survey (SKRT), the prevalence of anemia in pregnant women in Indonesia was $40.1 \%$ and in 2007 it drecreased to 24.5\%. Based on the results of the Basic Health Research (Riskesdas) in 2013 the prevalence of anemia in pregnant women in Indonesia increased to $37.1 \%$. Thus this condition indicates that iron nutrition anemia is still a public health problem (Paendong, 2016).

Based on the Medan Health Office in 2010, the anemia survey conducted in 4 districts / cities in North Sumatra, included Medan City, Binjai, Deli Serdang and Langkat Districts, was $40.50 \%$ of women suffer from anemia (Lubis, 2017).

There were several factors that influenced the incidence of anemia in pregnant women including gestational age, parity, pregnancy distance, iron (Fe) tablet consumption patterns, Upper Arm Circles (LiLA) measurements, nutritional status, education, employment and income (Yuria, 2015).

People who were highly educated will usually act more rationally. Therefore, educated people would more easily accept new ideas. Likewise, a highly educated mother will have her pregnancy checked regularly to maintain the health of herself and her child in the womb.

The higher the education correlated with the higher the awareness of the moth- er to get good nutrition so that it does not cause anemia in pregnancy. Anemic pregnant women with low education have a higher prevalence than highly educated mothers (Mariza, 2016).

Pregnant women from low socioeconomic classes experience an increased risk of developing anemia compared to higher socioeconomic classes. This can happen because people from low socioeconomic status do not have the ability to buy quality or quantity of food compare to people from high socioeconomic status (Addis, 2014).

Based on the above, the author was interested in examining whether there was a relationship between socio-economic levels and the incidence of anemia in pregnant women at Glugur Darat health center in 2018.

\section{SUBJECTS AND METHOD \\ 1. Study Design \\ This was an analytical method with a cross sectional approach, conducted at the Glu- gur Darat Puskemas in 2018.}

\section{Samples and Population}

Total 65 pregnant women at the Puskesmas Glugur were selected for this study by consecutive sampling.

\section{Study Variables}

The independent were the education level, job status, income level. The dependent variable was the incidence of anemia in pregnant women.

\section{Study Instruments}

Haemoglobin was measured by Easy Touch GCHb® and from the KIA book. Education level, occupational status, income level were obtained from a set of questionnaire.

\section{Data Analysis}

The data were analyzed by Chi Square. 
Journal of Maternal and Child Health (2019), 4(6): 48-56

https://doi.org/10.26911/thejmch.2019.04.06.05

\section{RESULTS}

\section{The characteristics of the study subjects}

Table 1 showed that of 65 pregnant women, there were 40 people who had anemia (61.6\%), while those who did not have anemia were 25 people (38.4\%).

Based on the results, 40 pregnant women with anemia who became respondents, pregnant women with anemia were 34 subjects $(85.0 \%)$ in the risk group, 22 subjects in the Multigravida group (55.0\%). ), Primipara group as many as 16 subjects (40.0\%), Trimester III pregnancy age were 27 subjects $(67.5 \%)$, secondary education were 28 subjects $(70.0 \%)$, not working were 31 subjects $(77.5 \%)$, medium income were 19 subjects $(47 \cdot 5 \%)$.

Table 1. Characteristic frequency distribution of pregnant women with anemia

\begin{tabular}{lcc}
\hline \multicolumn{1}{c}{ Variables } & n & \% \\
\hline Haemoglobin & & \\
Anemia & 40 & 61.5 \\
Not Anemia & 25 & 38.5 \\
Age & 6 & \\
Risky $\left(<20^{\text {th }}\right.$ and $\left.>35^{\text {th }}\right)$ & 34 & 15.0 \\
Not risky $\left(20^{\text {th }}-35^{\text {th }}\right)$ & & 85.0 \\
Gravida & 14 & 35.0 \\
Primigravida & 22 & 55.0 \\
Multigravida & 4 & 10.0 \\
Grandemultigravida & & \\
Parity & 13 & 32.5 \\
Nullipara & 16 & 40.0 \\
Primipara & 11 & 27.5 \\
Multipara & & \\
Age of Pregnancy & 3 & 7.5 \\
Trimester I & 10 & 25.0 \\
Trimester II & 27 & 67.5 \\
Trimester III & & \\
Education level & 6 & 15.0 \\
Primary & 28 & 15.0 \\
Middle & 6 & \\
Higher & & 22.5 \\
Occupational status & 9 & 77.5 \\
Working & 31 & 20.0 \\
Not working & & 47.5 \\
Income level & 8 & 22.5 \\
Low & 19 & 10.0 \\
Adequate & 9 & \\
High & 4 & \\
Very high & & \\
\hline
\end{tabular}

\section{Bivariate Analysis}

Table 3 showed in anemia category there were $28(43.1 \%)$ at the middle education, 6 (9.2\%) at the primary education and 6 people (9.2\%) at the tertiary education. In the non anemia category there were 12 (18.5\%) at the middle education, $4(6.2 \%)$ at the primary education and $9(13.8 \%)$ at the tertiary education. There was no significant relationship between the level of education and the incidence of pregnant women $(\mathrm{p}=0.125)$.

Based on occupational status, the largest percentage was in the unemployed work status with anemia amounting to 31 people (47.7\%) and those without anemia amounting to 17 people (26.2\%). Meanwhile, the smallest percentage was in the 
working status of working with anemia amounting to 9 people (13.8\%) and those who did not have anemia amounting to 8 people (12.3\%). There was no significant relationship between job status and the incidence of anemia in pregnant women $(\mathrm{p}=0.404)$.

Based on income levels, the largest percentage was at the middle income level where those with anemia were 19 people (29.2\%) and those without anemia were 6 people (9.2\%). At the high income level, there were 9 people (13.8\%) and those without anemia amounting to 14 people (21.5\%). At low income level, there were 8 people (12.3\%) and those who did not have anemia amounting to 3 people (4.6\%). The smallest percentage was at a very high income level where 4 people $(6.2 \%)$ were anemic and 2 people were not anemic (3.1\%). There was no significant relationship between the level of income and the incidence of anemia in pregnant women $(\mathrm{p}=0.052)$.

Table 2. Relationship Between the education level, occupational status, and income levels with the incidence of anemia in pregnant women

\begin{tabular}{|c|c|c|c|c|c|c|c|}
\hline \multirow{3}{*}{ Variables } & \multicolumn{4}{|c|}{ Haemoglobin } & \multirow{2}{*}{\multicolumn{2}{|c|}{ Total }} & \multirow{3}{*}{$\mathbf{p}$} \\
\hline & \multicolumn{2}{|c|}{ Anemia } & \multicolumn{2}{|c|}{ Not anemia } & & & \\
\hline & $\mathbf{N}$ & $\%$ & $\mathbf{N}$ & $\%$ & $\mathbf{N}$ & $\%$ & \\
\hline \multicolumn{8}{|l|}{ Education } \\
\hline Primary & 6 & 9.2 & 4 & 6.2 & 10 & 15.4 & \multirow{3}{*}{0.125} \\
\hline Middle & 28 & 43.1 & 12 & 18.5 & 40 & 61.5 & \\
\hline Higher & 6 & 9.2 & 9 & 13.8 & 15 & 23.1 & \\
\hline \multicolumn{8}{|l|}{ Occupation } \\
\hline Working & 9 & 13.8 & 8 & 12.3 & 17 & 26.2 & \multirow{2}{*}{0.404} \\
\hline $\begin{array}{l}\text { Not working } \\
\text { Income levels }\end{array}$ & 31 & $47 \cdot 7$ & 17 & 26.2 & 48 & 73.8 & \\
\hline Low & 8 & 12.3 & 3 & 4.6 & 11 & 16.9 & \multirow{4}{*}{0.052} \\
\hline Adequate & 19 & 29.2 & 6 & 9.2 & 25 & 38.5 & \\
\hline High & 9 & 13.8 & 14 & 21.5 & 23 & $35 \cdot 4$ & \\
\hline Very high & 4 & 6.2 & 2 & 3.1 & 6 & 9.2 & \\
\hline
\end{tabular}

\section{DISCUSSION}

The results of the study were obtained from 65 pregnant women, 40 people (61.5\%) were anemia and 25 people (38.5\%) without anemia. The results of this study were in line with the study conducted by Wiraprsidi, Kawengian, and Mayulu in 2017 which found that of 51 respondents, most of the 48 respondents (94.1\%) suffered from anemia, and only 3 respondents (5.9\%) did not suffer anemia. Anemia was a condition in which the body has too few red blood cells (erythrocytes), which red blood cells contain hemoglobin which functions to carry oxygen to all body tissues (Astriana, 2017). There were several factors that influence the incidence of anemia in pregnant women including gestational age, number of gravidas, number of parity, distance of pregnancy, consumption pattern of iron (Fe) tablets, measurement of Upper Arm Circumference (LiLA), nutritional status, education, employment and income (Yuria, 2015).

The results of this study found pregnant women who had anemia were $55.0 \%$ were Multigravidas. The more often a woman experiences pregnancy and childbirth, the more iron will be lost and the more anemic. The more often a woman was pregnant and giving birth, the greater the risk of developing anemia, because it depletes iron reserves in the body (Rizkah, 2017). 
Journal of Maternal and Child Health (2019), 4(6): 48-56

https://doi.org/10.26911/thejmch.2019.04.06.05

The results of the study showed that from 40 pregnant women with anemia, the largest percentage in the age group of atrisk mothers was 34 people (85.0\%), while the smallest percentage in the age group at risk was 6 people (15.0\%). This study was in line with the study conducted by Evi Desfauza in 2016, which was obtained from 79 pregnant women, there were 55 pregnant women (69.6\%) who had anemia at the age group not at risk and 24 pregnant women (30.4\%) who having an age group at risk. In healthy reproduction, the age that was safe for pregnancy and childbirth was 20 to 35 years. Pregnant women aged less than 20 years were at risk of anemia because adolescents want the ideal body so that it encouraged a strict diet without paying attention to nutritional balance, so that when entering pregnancy with malnutrition. While at the age of $>35$ years, it was associated with setbacks and decreased endurance and various diseases that often afflict this age (Astriana, 2017).

The results of this study found that the age group was not at risk in this study 8\% Multigravida and $32.7 \%$ Primigravida and $5.5 \%$ Grandemultravida. This could happen because anemia was affected by pregnancy and labor often, the more often a woman experiences pregnancy and childbirth, the more iron will be lost and the more anemic. The more often a woman is pregnant and giving birth, the greater the risk of developing anemia because the pregnancy experiences depleting iron reserves in the body (Astriana, 2017).

The results of the study showed 40 pregnant women with anemia the highest percentage were in the Multigravida group of 22 people (55.0\%), while the smallest percentage was in the Grandemultravida group of 4 people (10.0\%). This study is in line with the research conducted by Rizkah in 2017 , that of the 40 pregnant women who suffered from anemia, the largest percentage was found in the Multigravida group of 19 people (47.5\%) and the smallest percentage was in the Grandemultigravida group of 4 people (10.0 \%).

Manuaba states that anemia was affected by pregnancy and labor often, the more often a woman experiences pregnancy and childbirth, the more iron loses and the more anemic. The more often a woman was pregnant and giving birth, the greater the risk of developing anemia because the pregnancy was draining iron reserves in the body (Rizkah, 2017). The results of this study were not in accordance with the theory where the multigravida group suffered more anemia than the Grandemultravida group, but when compared with their fellow groups, there were 4 people (66.7\%) who were more anemic in the Grandemultigravida group than 2 people who were not anemic (33.3\%). In accordance with the theory said by Irul (2018), a mother who is often pregnant has a risk of anemia in subsequent pregnancies if she does not pay attention to nutritional needs (Rizkah, 2017).

The results of the study showed that the data from 40 pregnant women the largest percentage was in the Primipara group of 16 people (40.0\%) while the smallest percentage was in the Multipara group of 11 people (27.5\%). This study is in line with the research conducted by Wiwin in 2016, of 45 pregnant women with anemia, the largest percentage was found in the Primipara group as many as 29 people (62.4\%), while the smallest percentage was in the Multipara group amounting to 16 people (35.6\%).

The risk of anemia in pregnant women with high parity was related to maternal nutritional status. This was related to the reserves of iron in the mother's body which is drained during pregnancy to meet the needs of the fetus and placenta. If the 
next pregnancy occured when the maternal nutritional status was poor and the pregnancy distance is too close, the mother's body will not be able to recover the iron reserves that have been drained in the previous pregnancy, causing anemia in subsequent pregnancies (Paendong, 2016). A mother who has given birth is more than 3 times at risk of experiencing serious complications such as bleeding, this is influenced by the condition of anemia during pregnancy.

The results of this study are not in accordance with the theory where it was found that the majority of anemia was in the Primipara group, but when compared with their fellow groups, it was found that mothers with Multipara group suffered more anemia as many as 11 people $(78.6 \%)$ and those without anemia as many as 3 people (21.4\%). In accordance with the theory which says that the more often a woman gives birth, the greater the risk of blood loss and an impact on the decrease in Hb levels causing anemia (Paendong, 2016).

The results of the study showed that of the 40 pregnant women with anemia who became the respondents, the largest percentage was found in the Age of Pregnancy Trimester III amounting to 27 people (67.5\%) while the smallest percentage was the Age of Pregnancy Trimester I amounting to $3(7.5 \%)$ This study is in line with the research conducted by Herawati in 2010, namely from 44 pregnant women with anemia who became respondents, the largest percentage was in the Trimester III amounting to 24 people (54.5\%), while the smallest percentage was in Trimester I amounting to 2 people ( $8.3 \%$ ). The pregnancy period, especially the third trimester, was a critical period where the need for nutrients increases. If iron in the blood was lacking, the hemoglobin level would decrease which would cause interference and fetal growth. The iron needs of pregnant women were increased in trimester II and III pregnancies. The higher the gestational age of the mother, the greater the risk of anemia if it is not balanced with a balanced diet and regular consumption of Fe tablets (Herawati, 2010).

\section{The relationship between educa- tion level and the incidence of anemia in pregnant women}

From the results of this study, it was found that out of 40 pregnant women with anemia, it was found that the respondents who had anemia increased in respondents with secondary education, 28 people (70.0\%) more than other education. The level of education can influence the occurrence of anemia in pregnancy, because in education there is a process of developing one's knowledge, insight, competence and mindset (Nanda, 2017).

The low level of education of pregnant women will affect the receipt of information so that knowledge of iron ( $\mathrm{Fe}$ ) is limited and has an impact on the occurrence of iron deficiency. The low level of education is closely related to the level of understanding of $\mathrm{Fe}$ and its awareness of consumption of Fe tablets for pregnant women. Anemic pregnant women with low education have a higher prevalence than highly educated mothers. The level of education will influence a person to make a decision on an action, a highly educated mother will open up with the entry of new information so that it will increase the level of good knowledge that will influence positive behavior towards nutrition fulfillment during pregnancy (Mariza, 2016).

The results of the statistical test with chi-square showed, there was no significant relationship between the level of education and the incidence of anemia in this study. The results of this study are in line with the study of Yuria in 2015 entitled Factors Af- 
Journal of Maternal and Child Health (2019), 4(6): 48-56

https://doi.org/10.26911/thejmch.2019.04.06.05

fecting Anemia in Pregnant Women who examined the relationship of education to the incidence of anemia (o.348). The results of this study are not in line with the research of Yanti, Sulistianingsih and Keisnawati in 2015, revealing that there was a significant relationship between maternal education and the incidence of anemia in Pregnant Women in Pringsewu Lampung Public Health Center with $(\mathrm{p}=0.001)$

\section{The relationship between occupa- tional status and the incidence of anemia in pregnant women}

From the results of this study, it was found that out of 40 pregnant women with anemia who had been performed it was found that respondents who had anemia were more likely to be respondents with non-working employment status amounting to 31 people (77.5\%). Occupation was something that was done to get a living or the livelihood of people who were busy with activities or daily work would have more time to obtain information. Pregnant women who work refer to those who had income to help their husbands in fulfilling their daily needs. Pregnant women who had income are related to the ability of pregnant women to gain knowledge about anemia because of family finances (Kondi, 2017).

There was no significant relationship between working status and the incidence of anemia in this study. The results of this study are in line with the research conducted by Umi Fikriana in 2014 which examined the relationship of occupation with the incidence of anemia in pregnant women stated there was no relationship between occupation and anemia occurrence at the Kasihan II Bantul Health Center. Although the statistical test is not meaningful, when compared with fellow groups, it was found that the majority of mothers with nonworking groups were 31 people (64.6\%) and those who did not suffer from anemia were 7 people (35.4\%).

The results of this study are in line with the theory stated by Wiraprasidi et al (2017) that stated housewives who do not have jobs tend to have lower economic status so they have to do hard work during pregnancy to meet their needs. Pregnant women with employment status not only as housewives is one of the risk factors for anemia because most of the housewives whose income depends on their husbands to fulfill their daily needs. Some of these housewives have a low socioeconomic status. Anemia is found in women whose monthly income is low. From this study also, it can be seen that pregnant women who did not work but did not experience anemia, according to authors, this happened because even though the mother did not work, and her family had low income, her knowledge was quite high, where the mother always got the latest information about iron needs when pregnant, prevention of anemia during Integrated Antenatal at Glugur Darat health center.

\section{The relationship between income level and the incidence of anemia in pregnant women}

From the results of this study, it was found that the majority of respondents who experienced anemia were in the middle / adequate income group were 19 people (47.5\%). Income refers to all receipts in the form of money or money, both from outside parties and from the results themselves, by way of being assessed for a number of prices on goods that were valid at that time in the form of money. The income earned by a person influenced the movement of life and reaction in the community because the size of the income will affect the purchasing power of fulfilling the needs of life (Pinem, 2016). 
Noviyanti et al./ The Relationship between Social Economic Levels and Anemia

There was no significant relationship between the level of income and the incidence of anemia in this study. The results of this study are in line with the research conducted by Sugiarsih in 2013 entitled relationship between the level of socio-economics and the level of haemoglobin Although the statistical test is not meaningful, when compared with fellow groups, it was found that mothers with low income group were the majority of anemia amounting to 8 people $(72.7 \%)$ and those who were not anemic amounting to 3 people (27.3\%). It was in accordance with the theory which says that income is closely related to economic status. Lack of family income leads to reduced daily food purchases thereby reducing the number and quality of mother's food per day which has an impact on reducing nutritional status (Nanda, 2017).

The food sources needed to prevent anemia generally come from protein sources that are more expensive, and difficult to reach for those on low incomes. This deficiency increases the risk of anemia in pregnant women and exacerbates the risk of morbidity in mothers and newborns (Liow, 2012). Based on this study, it can be concluded that there is no relationship between socioeconomic level and the incidence of anemia in pregnant women at the Glugur Darat health center in 2018.

\section{AUTHOR CONTRIBUTION}

Berliana Noviyanti collected data, described the data, and wrote the article. Harry C Simanjuntak suggested for discussion. Eka Samuel P Hutasoit gave comment and suggestion for this study. Hendrika A Silitonga and Endy Julianto examined the conceptual framework and methodology.

\section{FUNDING AND SPONSORSHIP}

This study used the author's independent fund.

\section{CONFLICT OF INTEREST}

There is no conflict of interest in this study.

\section{ACKNOWLEDGMENT}

We would like to thank Glugur Darat Puskemas for assistance in the data collecting.

\section{REFERENCE}

Api O, Breyman C, Çetiner M, Demir C, Ecder $T$ (2015). Diagnosis and Treatment of Iron Deficiency Anemia during pregnancy and the postpartum period. Turkish Journal of Obstetrics and Gynecology. Retrieved from https://www.ncbi.nlm.nih.gov/pmc/articl es/ PMC5558393/ on 02 March 2018.

Astriana W (2017). Kejadian anemia pada Ibu Hamil ditinjau dari Paritas dan Usia (Anemia in pregnant women in terms of parity and age). Jurnal Ilmu Kesehatan 2 (2). Retrieved from http://ejournal.stikesaisyah.ac.id/index .php/jika/article/download/WA/pdf.

Herawati C, Astuti S (2010). Faktor-faktor yang berhubungan dengan Anemia Gizi pada Ibu Hamil di Puskesmas Jalaksana Kuningan (Factors Associated with Nutritional Anemia in Pregnant Women at Jalaksana Kuningan Heal th Center). Jurnal Kesehatan Kartika 2(1) Retrieved from http://www.stikesayani.ac.id/publikasi/ejournal/filesx/2010/201012/201012-007.pdf.

Irul $H$ (2018). Hubungan Jumlah Paritas dan Umur Kehamilan dengan Kejadian Anemia Ibu Hamil (The Relationship of the Number of Parity and Age of Pregnancy with the Occurrence of Anemia in Pregnant Women). 2(1) Retrieved from http://jurnalfpk.uinsby.ac.id/index.Php/jhsp/article/download/113/92/.

Ministry of Health (2015). Direktorat Jendral Bina Gizi dan Kesehatan Ibu dan Anak. Pedoman Pelayanan Antenatal 
Terpadu Edisi Kedua (Second Edition of Integrated Antenatal Service Guidelines). Jakarta: Kementrian Kesehatan RI: 10 - 11 .

Liow FM, Kapantow NH, Malonda N (2012). Hubungan antara status sosial ekonomi dengan anemia pada ibu hamil di Desa Sapa Kecamatan Tenga Kabupaten Minahasa Selatan (The relationship between socio-economic status and anemia in pregnant women in Sapa Village, Tenga District, South Minahasa Regency) 1(10). Retrieved from http://fkm.unsrat.ac.id/wpcontent/article/uploads/2013/o8/M.Liow.pdf.

Maskey M, Jha N, Poudel SI, Yadav D (2014). Anemia in pregnancy and its associated factors: A study from Eastern Nepal. Nepal Journal-INASP. 4(4). Retrieved from https:// www.nepjol.ifo/idex.php/NJE/article/dow nload/11358/9205.

Paendong FT, Suparman E. Tendean HMM (2016). Profil zat besi (Fe) pada ibu hamil dengan anemia di Puskesmas Bahu Manado. Jurnal e-Clinic (eCl), 4(1). Retrieved from https://ejour nal.unsrat.ac.id/index.php/eclinic/article/viewFile/10985/1054.

Pinem, Mbina (2016). Pengaruh Pendidikan dan Status Sosial Ekonomi Ke- pala Keluarga bagi Kesehatan Lingkungan Masyarakat (The Influence of Education and Socio-Economic Status of the Family Head for Community Environmental Health), 4(1) Retrieved from. https://ojs.uma.ac.id/index.php/jppuma/article/download/896/896.

WHO (2017). Anaemia as a Public Health Problem. Retrieved from http://apps.who.int/iris/btream/handle/10665/259425/9789241513067eng.pdf?se quence $=1$.

Yuria, Mella, Mulyasari, Tri (2015). Faktor yang mempengaruhi anemia pada ibu hamil (Factors that affect anemia in pregnant women). 1(10). Retrieved from http://impuls.binawan-ihs.ac.id/ojsindex.php/jisb/article/view$/ 10 / 6$.

Yanti DAM, Sulistianingsih Apri and Keisnawati. (2015). Faktor-faktor Terjadinya Anemia pada Ibu Primigravida di Wilayah Kerja Puskesmas Priwingsewu Lampung (Factors of Anemia Occurrence in Primigravida in the Priwingsewu Public Health Center Lampung). 6(2) Retrieved from http://download/portalgaruda.org/ar ticle.php?article $=424747 \& \mathrm{val}=278 \&-$ title. 